\title{
Hudba a rituál
}

\author{
Lubomír Tyllner
}

DOI: 10.21104/CL.2016.4.06

\section{Music and ritual}

Abstract Study of rituals can rarely do without the examination of music which constitutes an important non-verbal part of their structure. The process of rituals correlates with music which determines the rhythm of changes. The study is based on field research of the annual spring ritual cycles in Bohemia, Slovakia and Basel, Switzerland, which are compared. Music in rituals can be applied in two forms: as protocolar (becoming the identifier of the ritual) or arbitrary. The processes of the Shrovetide rituals are interpreted according to Gennepov classification of transitional rituals with the key feature of the liminal (threshold) phase; in the same way Victor Turner's terms such as communitas and anti-structure are applied.
Keywords traditional music, ritual, ceremony, carnival, fasnacht, ethnomusicology, liminality, antistructure, communitas, Arnold van Gennep, Victor Turner.

Příspěvek byl zpracován s institucionální podporou Etnologického ústavu AV ČR, v. v. i., RVO:68378076.

Contact Doc. PhDr. Lubomír Tyllner, CSc., Etnologický ústav AV ČR, v. v. i., Na Florenci 1420/3, 11000 Praha 1, Czech Republic; e-mail: tyllner@eu.cas.cz.

Jak citovat/How to cite Tyllner, Lubomír. (2016). Hudba a rituál. Český lid 103, 635-654. doi:http:// dx.doi.org/10.21104/CL.2016.4.06 
Rituál, ritus, ${ }^{1}$ patří k frekventovaným pojmům v oblasti etnologie, sociální a kulturní antropologie, religionistiky, teatrologie, muzikologie a řady dalších společenskovědních oborů. Často je zastupován nebo zastupuje pojmy slavnost (koná se ad hoc, nemusí být vázána na konkrétní datum, nemusí se řídit dlouhodobě respektovanými pravidly, počítá s větším množstvím účastníků, bývá politicky, společensky motivovaná), ceremoniál, obřad (má spíše okázalý dějový charakter), obyčej, zvyk resp. soubor zvyklostí (opakované chování, často norma, ne ale takové závažnosti a významu, jako má rituál²). Obřady a rituály rovnocenně staví vedle sebe Claude Lévi-Strauss (2006: 16), pojem rituál se objevuje v podtitulu publikace Thomase H. Eriksena Sociální a kulturní antropologie (2008) spolu se souvisejícími pojmy příbuzenství a národnostní příslušnost. O slavnostech, ceremoniích a rituálech jedním dechem například hovoří historikové František Šmahel a Martin Nodl (2014), stejně tak pojmy obřad a rituál často zástupně užívá i Arnold van Gennep (1997).

Jasný, jednotný a vyčerpávající výklad pojmu v esencialistickém duchu (co je podstatou rituálu, co je v něm stálé, co bylo na jeho počátku a je v něm trvale obsaženo) v podstatě omezuje dynamický vývoj pojmu i definování samotného rituálu. Ne zcela uspokojuje nominalistické pojetí, tedy neplatí obecná shoda na tom, jak má být danému pojmu rozuměno, nebot́ terénní realita termínu rituál je v hovorovém jazyce jiná než významová konvence odborné literatury a odborného jazyka. Podobně i sami účastníci rituálu, respektive informanté používají pojem různě, nebo ho nahrazují výrazy odlišnými, jakkoli významově příbuznými.

Z mimořádně bohaté literatury, zabývající se rituály, ze slovníkových hesel a zejména z popisů a charakteristik nejrůznějších rituálů v odlišných prostředích je možné vymezit dlouhou řadu společných nebo většinově se vyskytujících znaků. Rituálem je obvykle označován opakovaně uplatňovaný způsob jednání a chování probíhající podle tradicí stanovených pravidel. K hlavním znakům patří sled rituálních úkonů, pevné pořadí dějových kroků, tzv. obřadní sekvence (van Gennep 1997: 19) a s tím související formalizované (ustrnulé), identicky opakované, stereotypní chování a děje. Rituály přispívají ke stabilizaci a udržení integrity společenství (Gluckman 1962), k posílení sdílených hodnot a odbourání generačních rozdílů. Tím napomáhají k udržení hospodářské utilitarity nejrůznějších komunit. Účastníky rituálu spojuje společný prožitek, společné myšlení a tím - třeba jen dočasně - určité sociální pouto. V průběhu času rituál prochází jen malými obměnami, naopak výrazné změny signalizují postupnou přeměnu, folklorizaci rituálu, či jeho zánik.

1 Pojem původně spojovaný se svátostními úkony (Rituale romanorum). Pro soubor zvyklostí pravidel a pořadí bohoslužebných úkonů v závislosti na jednotlivých církvích (rovněž z hlediska hudebního) je přednostně užíván pojem ritus. 
S rituálem často souvisí rituální jazyk (mluva, promluva³), oblečení nebo strava. Rituály mají funkci magickou, stávají se druhem psychoterapie (očistné rituály), provází je napětí, očekávání a někdy změněné vědomí. ${ }^{4}$ Bývají spojeny s kultem, posvátnou úctou, religiózními cíli, čemuž odpovídá jejich dějový průběh se slovy, gesty a ději probíhajícími za přesně stanovených pravidel. Rituály vyrůstají z tradice, původně byly a mnohde stále jsou ústně předávané, později také písemně fixované.

Autorem základní práce věnované rituálu je francouzský etnolog Arnold van Gennep, (1873-1957) jehož dílo Les rites de pasage. Étude systématique des rites (1909, česky Přechodové rituály. Systematické studium rituálů,1997) je zdrojem inspirací i pro dnešní studium rituálu, podobně jako dílo Victora Turnera (1920-1983) The Ritual Process: Structure and Anti-Structure (1969, česky Průběh rituálu, 2004), které dílo van Gennepa zejména z hlediska liminální fáze rituálu dále rozvíjí. Řadu podnětů rovněž přináší studie Roy A. Rappaporta, Ritual and Religion the Making of Humanity (2002) nebo soubor referátů Musik und Ritual - Fünf Kongressbeiträge, zwei freie Beiträge und ein Seminarbericht (Barthelmes - De la Motte-Haber 1999).

Jejich práce, nejen poslední jmenovaný sborník, jsou inspirací i pro zkoumání hudebních projevů, nebot právě ty (at' již ve smyslu fónickém, nebo prostě vnějším, ornamentálně-dekorativním) tvoří nápadnou, znakovou součást rituálů. Hudba se stává aktivní součástí jejich struktury, pokud původně přítomná hudba z nich mizí nebo je deformovaná (ne-autentická), znamená to porušení čistoty rituálu nebo jeho zánik. Jestliže rituály samy o sobě slouží k integraci členů společenství, pak hudba jako specifický způsob estetického vyjádření, jako významný emoční a současně univerzální výrazový prostředek k tomuto propojení přispívá. A bereme-li v úvahu, že víra a náboženství se projevují především rituály, potom hudba je v nich zastoupena téměř privilegovaně.

Je tomu tak proto, že hudba nejen v tradičním společenství je integrována do mnoha aktivit člověka, nositele osobní i kolektivní identity. Také dnes je nepostradatelným prostředkem pro nastolení a udržení soudržnosti skupiny. Hudba se vyskytuje v chrámu stejně jako v obchodech, ve svatební síni i v krematoriu, na technoparty, na večírcích s kytarou či s cimbálem. Zní ve sluchátkách lidí různých generací, sportovců připravujících se na sportovní výkon. Je přítomna v situacích posvátných i světských, využívá se jako terapie, výchovný prostředek, je provozována prostřednictvím zpěvu, hry na hudební nástroj (sólově nebo ve skupinách) a vstupuje do domácností či kamkoli jinam skrze média. Pozoruhodným způsobem podporuje tendence nacionální, stejně jako internacionální a globální. V minulosti se stávala zvláště působivou prvotními zvukovými prostředky: bubnováním, které bylo vydatným zdrojem

3 Např. proslovy ke svatebnímu rituálu shrnul František Jan Vavák (1741-1816) v př́ručce Smlouvy, aneb chvalitebné řeči svatební (1802). I když postupně docházelo k proměně hovorového i spisovného jazyka, dochovaly si jeho obřadní promluvy svou autentickou podobu hluboko do 20. století. Např. u nestinarských rituálů v Bulharsku v pohoří Strandža (Nejkova - Fol 2000). 
akustických a zejména rytmických impulzů stejně jako je jimi dnes v nejrůznějších proudech populární hudby, intonačně modulovanými nářky nad mrtvými, nebo akustickými vlnami a signály zvonů. Oproti koncertní nebo populární hudbě se však nemusí jednat jen o kultivované zvukové projevy, které jsou „výlučným dílem kultury“ (Lévi-Strauss 2006: 35). Může jít také o nejrůznější zvuky vydávané vlastním tělem, tleskáním, pískáním, křikem, hysterickým sténáním, jindy také výstř̌ely z pušek a kanónů.

Rituální funkci hudby lze objevit i tam, kde ji prvoplánově nehledáme. Rysy rituálu či ritualizovaného chování v sobě například nese provozování umělecké hudby. Publikum přichází do koncertní síně poslouchat a vnímat mnohonásobně opakovanou, často i dobře známou skladbu, dostupnou z řady zvukových nosičů, navíc většinou v mnohem dokonalejší interpretaci, než se uskuteční na koncertním pódiu. Akcent prožitku není ani tak soustředěn na hudební dílo, ale na související dění: na přípravu společenské události, napětí v sále před příchodem umělce a samotný jeho příchod, na oblečení, způsob úklony a obecně na komunikaci s publikem, na chování umělce (dirigenta) při interpretačním výkonu, přičemž výkon sám nemusí být tím prvořadým (pokud třeba nejde o fatální selhání umělce). Součástí koncertního rituálu je přestávka s korzem, často se sektem a dialogem při náhodném nebo předpokládaném setkání s přáteli o přestávce koncertu.

Hudba př́tomná v rituálu v sobě obsahuje dvojí afiliaci: je určena jednak těm, kteří rituál a v něm přítomnou hudbu provozují, jednak těm, kteří rituál vnímají, ale nejsou jeho př́mými realizátory, aktivními aktéry. ${ }^{5}$ Binární opozici tvoří i ty druhy hudby, které k rituálu stojí ve vztahu podmiňujícím (přímá závislost hudebního repertoáru na typu a ději rituálu), nebo nezávislém, arbitrálním, kdy hudba více či méně jakákoli je v něm prostě přítomna. V případě prvém se hudba stává identifikačním znakem rituálu a hovoříme o hudebních projevech protokolárních (povinných, nezaměnitelných), v případě druhém o projevech volných, proměnlivých, nezávislých. Rituál a hudba zde stojí ve vztahu Saussurovou terminologií nazývaném signifiant, označující (příslušná protokolární hudba) a signifié, označované (vlastní rituál).

Jiná dualita se vztahuje k protokolární hudbě samotné. Jakkoli jde o hudbu „povinnou“, nezaměnitelnou a znakovou, její podoba, hudební obsah a forma ještě nemusí být přímým produktem (otiskem) rituálu, nebot tato hudba často nespodobňuje konkrétní dějový obsah, ačkoli je s ním tradičně spojována. Jinými slovy: čitelnost této hudby jako znaku rituálu vzniká až na základě konvence daného kulturního prostředí a na základě příslušných jazykových a významových konotací, v podstatě ale důsledkem informací až druhého řádu. Rituální hudba v pravém slova smyslu je hudbou z rituálu přímo vzešlá, s dějem rituálu související každým svým taktem, rituálem podmíněná nebo dokonce děj rituálu přímo vyjadřující a tím i vysvětlující. Př́íkladem takového vztahu 
hudby a rituálu je dílo Igora Stravinského (1882-1971), proslulý balet Svěcení jara (1913). Skladba je volnou parafrází mýtu z pohanského Ruska. Úvodní tance na úpatí posvátné hory oslavují příchod jara a rozehrávají obraz probuzení země. Nechybí frenetické tance, věštba ani obět. Vyvolená dívka se stane obětí bohu Yarilovi tím, že se utancuje k smrti. Hudba sama zde modeluje př́íběh, který se - a to je podstatné - $\mathrm{z}$ hudební představy zrodil až sekundárně. Naopak, slavné dílo Fryderyka Chopina (1810-1849) Smuteční pochod z klavírní sonáty b moll (1839) je př́kladem arbitrárního vztahu hudby a rituálu. Skladba vznikla jako kontrastní volná věta slavného Chopinova sonátového díla a teprve sekundárně se stala hudbou (a znakem) smutečních obřadů, třebaže pro tyto účely nevznikla. ${ }^{6}$ Dnes je hojně využívána jako mnohokrát se opakující smuteční pochodová hudba zejména při pohřbech státníků. ${ }^{7}$ Hudba je zde primárně součástí uměleckého díla bez vztahu ke smutečnímu ději, ale sekundárně se stala součástí nejen státního, ale i občanského smutečního rituálu.

Mezi uměleckou hudbou a tradiční hudební kulturou je však řada rozdílů, které omezují přímou komparaci různých druhů rituální hudby. Zatímco Svěcení jara stejně jako jiná díla tohoto charakteru jsou určena k jevištnímu provedení a platícímu publiku, tradiční hudba je přístupná jak aktivním realizátorům rituálu, tak i pasivním pozorovatelům. Polarita také spočívá v odlišnostech profesionální a amatérské hudby a rovněž v tvorbě individuální a kolektivní. Profesionální tvorba (tvorba na odbyt) je definována jako hudební kultura vyznačující se dlouhodobým a systematickým vzděláváním tvůrců usilujících o individuální, originální umělecké dílo a uznání jeho hodnot veřejností. Naopak amatérská kolektivní tvorba je vytvářena na objednávku společenství, skupiny, obyvatel regionu nebo národa, je pouze okrajově zasažená školskou vzdělaností a respektuje zákonitosti kolektivní tvorby a kolektivního vkusu (Tyllner 2010: 175-180).

Na tuto kolektivní tradici, kulturu „neelit“, byly v letech 2002-2016 soustředěny výzkumy výročních rituálů, jejichž významnou součást tvořila hudba ${ }^{8}$ Detailnější komparaci umožnily zejména rituály (obřady) konce předpostní doby, tzv. konce masopustu, které dobou konání, průběhem a s nimi souvisejícími úkony a zvyklostmi jsou obecně chápány jako rituály přechodu zimy a jara. Celou řadu společných a také jedinečných projevů včetně hudebních bylo možné sledovat na moravsko-slovenském pomezí ve Strání (region

6 Charakter smutečního pochodu má řada vět symfonických nebo komorních skladeb: věty symfonií Gustava Mahlera (1860-1911), druhá věta Klavírního tria g moll Bedřicha Smetany (1824-1884) aj.

7 Skladba byla důvěrně známá a jako smuteční hudba zafixovaná široké veřejnosti v době tří následných monstr pohřebních rituálů sovětských komunistických vůdců v letech (1982-1985).

8

Jedná se o výzkumy uskutečněné např. v Bulharsku (Bulgari, Svatá Varvara, 2002,

2003, 2004), v Rakousku (Böckstein, 2008, 2011), v Německu (Lužice, 2005, 2007,

2008), v Chorvatsku (Korčula, 2008) na Sardinii (Sedilo, 2006), v Itálii (Benátky, 2013),

ve Španělsku (Malaga, 2012), Polsku (Krakow, 2016), ve Švýcarsku (Basilej, 2015), u nás na Doudlebsku (Dobrkovská Lhotka, Slavče, 2001, 2002, 2005), na Kopanicích (Strání, 2008, 2010, 2014) a na slovenském Záhoří (Borský Mikuláš, Šaštín, 2009, 2010). 
Kopanice), na Slovensku nedaleko hranic s Moravou v obci Borský Mikuláš (region Záhoří) a v Dobrkovské Lhotce v jižních Čechách (region Doudlebsko). Jako př́ḱlad západoevropské městské masopustní tradice byla zvolena proslulá basilejská Fasnacht se zásadním podílem hudby v období tří závěrečných masopustních dnů.

Večerní společná zábava ${ }^{9}$ s půlnočním pochováním masopustu ve Strání (S) a Borském Mikuláši (BM), v Dobrkovské Lhotce (DL) s podvečerním zastřelením Masopustu, představuje okamžik přechodu bujarosti v předvelikonoční půst, tedy charakteristický projev liminality van Gennepovského typu. Sled úkonů, dějů a souvisejících hudebních projevů zde probíhá v přísně dodržované sekvenci, která je rovněž obecným znakem rituálové situace. Nápadnou podobnost tř́ zkoumaných rituálů v Čechách, na Moravě a na Slovensku navíc zdůrazňuje společný hudebně-taneční projev s použitím dřevěných šavlí (na Doudlebsku se v posledním období tato „výzbroj“ z tance vytratila), tzv. mečový tanec, prokazující dříve odhodlání, dnes především šikovnost tanečníkủ. ${ }^{10}$ Základní shody a příbuznosti lze přehledně shrnout:

- Obchůzka uskutečňovaná chlapci

(BM, S, DL)

- Protokolární průběh

(BM, S, DL)

- Protokolární písně a melodie

(BM, S, DL)

- Instrumentální doprovod (dechová nebo i hudecká hudba, kombinace s akordeonem ${ }^{11}$ ) (BM, S, DL)

- Kolo jako taneční půdorysový znak rituálu

(BM, S, DL)

- Společný tanec s domácími po vykonání obřadu u domu

(BM, S, DL)

- Společná zábava v hospodě na konci masopustu

(BM, S, DL)

- Ceremoniáŕr: richtár a slaninár

gazda

matka Masopust, rychtář a hejtman

- Šavle

(BM, S, původně také $\mathrm{DL}$ )

- Vyplácení kop (vytínání)

(BM, S, DL)

- Rychtářská ferule

(DL, BM)

- Obřadní oděv

(BM, S, DL)

- Masky, maškarády

(BM, S, DL)

- Obřadní strava

(BM, S, DL)

- Patriarchální a agrární akcent

(BM, S, DL) zábavy způsobují přesun data konání na předcházející sobotu a neděli nebo na jiné dny. 
Příprava a konání těchto rituálů nebývá dílem jedné generace, třebaže podíl mladých je výraznější v Borském Mikuláši a v Dobrkovské Lhotce. Obchůzka ve Strání se dnes uskutečňuje i dětmi školního nebo předškolního věku. Začlenění několika generací je zjevné ve všech případech minimálně účastí na večerní taneční zábavě. Vystoupení skupin koledníků před domy či na dvorech jednotlivých stavení, také v hospodě, na obecním úřadu nebo ve veřejných institucích (mateřská školka, škola, dům seniorů) má charakter divadelního výstupu ${ }^{12}$ zakončeného společným tancem. Podíl náboženských elementů v rituálech obvykle přítomných zde nalézáme v různé podobě, respektive $v$ různé intenzitě vnímaného náboženského kontextu. V Dobrkovské Lhotce není místo zahájení rituálu spojeno s církevním objektem, zato celý rituál je inspirován biblickým dějem křížové cesty. Ve Strání tvoří východisko rituálu prostor před chrámem a první zastávka koledníků patři faře a místnímu knězi. ${ }^{13} \mathrm{~V}$ Borském Mikuláši účastníci obchůzky nejprve společně navštíví dopolední mši svatou.

Jestliže rituál v obecném slova smyslu je projevem kolektivní shody a společných představ o koexistenci uvnitř společenství, v našem případě jsou výslednicí takového chování dílčí projevy rituálu - hudba, píseň a tanec. Jejich podoba je podmíněna několika okolnostmi: tím, že ve třech prvně zkoumaných lokalitách jsou hudba a tanec zásadním způsobem přítomny při zastávkách koledníků u jednotlivých stavení, domácností či institucí a dále rovností všech, smazáním rozdílů například mezi starostou obce, farářem, učitelem, úspěšným podnikatelem i nejnižšími společenskými vrstvami, tedy projevy antistruktury v turnerovkém slova smyslu. Proto formální i obsahový rámec performance musí být akceptovatelný všemi vrstvami obyvatelstva a hudba má, alespoň v základní protokolární podobě, odpovídat potřebám a možnostem hudebního projevu koledníků a možnostem percepce a sankcionizace těchto projevů místními obyvateli. V hudební praxi to znamená položení akcentu na obvyklé regionální melodické postupy, regionální nebo dokonce lokální hudební idiomy. Rituální tradice, její dlouhodobost, může být příčinou hudebních archaismů především v melodice nebo tonalitě. Rovněž přítomnost tance determinuje metrickou a rytmickou strukturu hudby. Významná je i skutečnost, že obchůzka většinou trvá celý den a je náročná pro hudebníky nátrubkových nástrojů, kteří zpravidla večer ještě absolvují taneční zábavu. Hudební instrumentář je rovněž podřízen potřebám neustálého přesunu hudebníků. Akordeon je v takovém případě praktickým nástrojem, třebaže v tradiční hudbě a obvyklých nástrojových sestavách většinou zastoupena nebývá. Vhodné jsou i akusticky výraznější žest'ové nástroje (oproti sestavám smyčcovým, hudeckým), které tolik netrpí rozmary masopustního počasí (déšt', sníh, mráz).

12 K otázkám vztahu rituálu a divadla viz Turner 1982.

13 Diskuse mezi mladými koledníky o zahájení obchůzky skončila slovy malého gazdy: „Nejprve k panu farárovi, taková je tradice!” 
Na Záhoří v Borském Mikuláši je Búranský fašank ${ }^{14}$ časově rozprostřen do tří dnů. V neděli začíná mší svatou, pokračuje maxikolem na centrálním prostoru obce a společnou hostinou pod širým nebem. Tanečníci ve velkém kruhu a velkém obsazení předvádějí všechny taneční varianty mečového tance založeného jak na zručném zacházení s šavlemi, na podtáčení a překračování, tak i na stereotypním poskoku, respektive podtrhávaném kroku, který je důsledně uplatňován v průběhu tří masopustních dnů. Maxikolo, hrdost místních občanů, je nepochybně novotvarem, avšak efektně splňuje funkci zahájení masopustního třídení a vytvoření rámce pro slavnost obyvatel obce. V hospodě večer za účasti tří vydatně exponovaných akordeonů pokračuje zábava, ve které hlavní roli hrají koledníci, rozhodující aktéři zítřejší obchůzky - klíčového obřadu druhého dne konce masopustu. Třetímu dni, masopustnímu úterý, dominuje večerní zábava a liminální situace s centrálním dějem pochování basy - symbolického konce bujarého veselí a počátku velikonočního půstu.

Hudební složka búranského masopustu je charakteristická dvěma protokolárními, stále se opakujícími melodiemi. První zdánlivým počátkem na sedmém stupni tóniny působí spíše jako druhý hlas nosnější základní melodie obvyklého dur/mollového zakotvení. Ve skutečnosti se však jedná o melodii ve frygickém modu, jejíž závěry frází zdůrazňují povzbudivá zvolání:

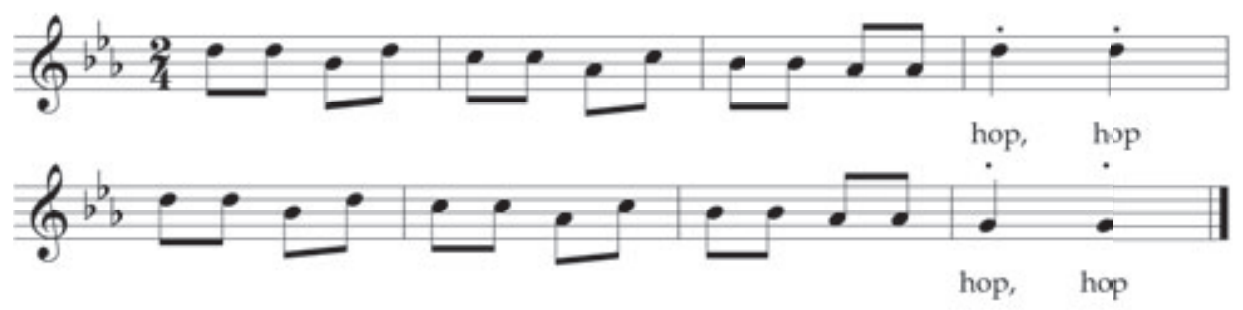

Tanec s dřevěnými šavlemi doprovází nástrojová sestava ve složení dvě křídlovky, žestový tenor s barytonem, buben s činelem, dva klarinety, tuba. Nástrojové skupiny (kromě stále přítomné tuby a bubnu s činelem) se střídají v sólech, zpravidla synchronně se změnou tanečních figur. Jejich sled určuje richtár se zdviženým rychtářským právem - ferulí. Začíná povelem do kolesa a pokračuje, hore šable, poskok, po mikulášsky... Protokolární část končí trojím zvoláním číjsou fašanky spolu s odpovědí koledníků naše a závěrečným akordem doprovodné muziky. Jinou skupinu koledníků doprovázejí dva klarinety, dva saxofony, akordeon a buben s činelem. Hudebníci se někdy pouštějí do odvážnějších variací a činí tak i tanečníci komickou taneční variantou vleže. Do hry, zejména při přesunu koledy, vstupuje neočekávanými, trochu potouchlými údery a synkopickými rytmy činel. Scéna před jednotlivými domy často končí vyplácením kop, zvednutím muže nebo ženy ve vodorovné poloze nad hlavy koledníků a symbolickými třemi údery rychtářskou ferulí. Vyplácení avizuje fanfára: 


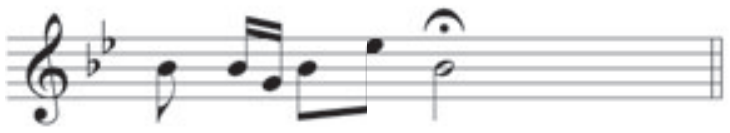

Koledníci jsou pohoštěni zpravidla pálenkou. Tam, kde jsou přítomna děvčata, se na závěr jednotlivé zastávky tančí (bez pokusu o regionální taneční projev) polka nebo valčík. Maškarády, například skupina mužů à la „Mexikánư“, provázejí průběžně postup koledníků a baví sebe i přihlížející nejrůznějšími šprýmy a vybíráním finančních příspěvků do kasičky. Ve dvojstupu a za zvuku druhé protokolární melodie odchází skupina koledníků ve volném pochodovém tempu i s hudbou $\mathrm{k}$ dalšímu domu. $\mathrm{V}$ hudbě je ojediněle patrný tzv. lombardský rytmus (obrácený vzhledem k rytmu tečkovanému), prozrazující vliv novouherského hudebního stylu.

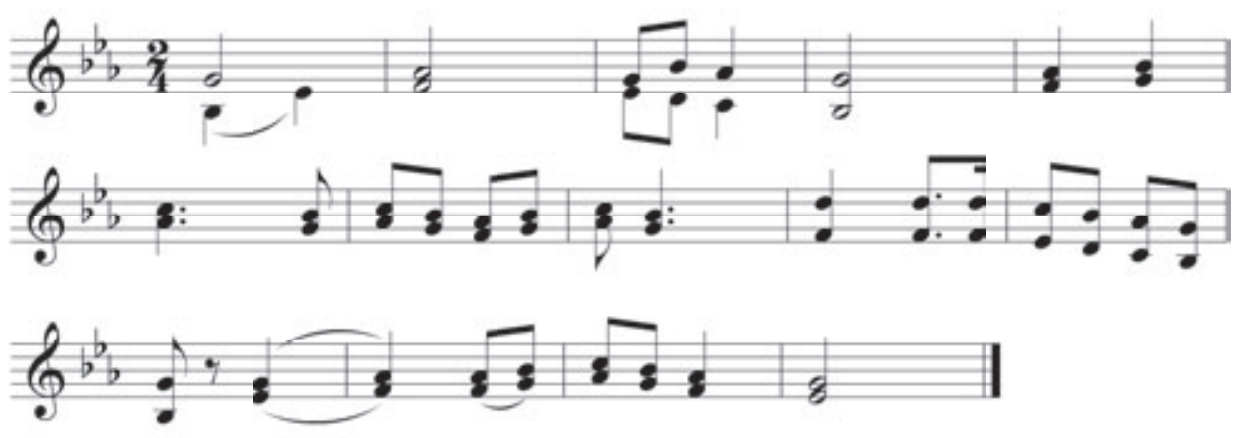

Obě melodie formální přehledností, periodicitou a jednoduchými údernými rytmy jsou tvarovány jak obecnými pravidly hudebního myšlení, tak i požadavkem výrazného doprovodu k tanci podšablářů. O masopustním úterý v Borském Mikuláši, při večerní taneční zábavě, k předváděnému protokolárnímu hudebně-tanečnímu rituálu hraje pouze akordeon. Dechovka, obstarávající taneční hudbu celého večera, v tomto případě př́tomna není. O půlnoci přichází vyvrcholení. Průvod krojovaných mládenců za exaltovaného nářku „pozůstalých“, maškarád a za zvuku smutečního pochodu přináší na márách basu. Komická figura kněze v ornátu a se štolou celebruje obřad posledního rozloučení a pronáší proslov ke zcela zaplněnému sálu s vypočítáváním hříchů obyvatel obce. Odchodem a pochováním basy vše končí, začíná půst.

Fašank ve Strání. Geografická blízkost a kulturní kontakty Borského Mikuláše a Strání na moravsko-slovenském pomezí přirozeně generují řadu vzájemných příbuzností. I zde mají děje o masopustním úterý charakter přechodového rituálu, kterým končí předpostní období a začíná velikonoční půst. Shodné je obcházení stavení a domácností (koleda) a také 
taneční projev podšablářů, cyklus pevně provázaných písní, tanečních figur a hudebního doprovodu. I když má s Borským Mikulášem řadu shodných prvků, odlišný je zpěvní a vůbec hudební doprovod a vlastní struktura opakované performance skupin hudebníků a tanečníků při obchůzce. Můžeme hovořit o rituálu sui generis, který je zároveň součástí rámcového masopustního přechodového rituálu (rituál v rituálu) jako celku.

Zahájení obchůzky se obejde bez počáteční mše aktérů koledy. Zato všichni účastníci, dospělí muži, chlapci, děti a mezi hudebníky i děvčata, přicházejí průvodem a za doprovodu hudby ze sálu kulturního domu ke schodišti místního kostela. Společný fotografický dokument se stane zprávou přištím generacím o kultuře a tradicích jejich předků.

Vlastní obchůzka začíná na faře a na obecním místním úřadě. Tam, kde se koledníci zastaví, jsou pohoštěni pálenkou, klobásou, pečivem a zejména koblihami. Hlavní ceremoniář, tentokrát gazda, věší klobásy a lahve s pálenkou jako trofeje na stále více zatěžkávanou hůl. Rituál je při každé zastávce koledy tvořen zpěvem, hudbou a tancem, opět částí protokolární a volnou. Zpěvní úvod a závěr má pozvolný, parlandový charakter a tvoří rámec celé performance:
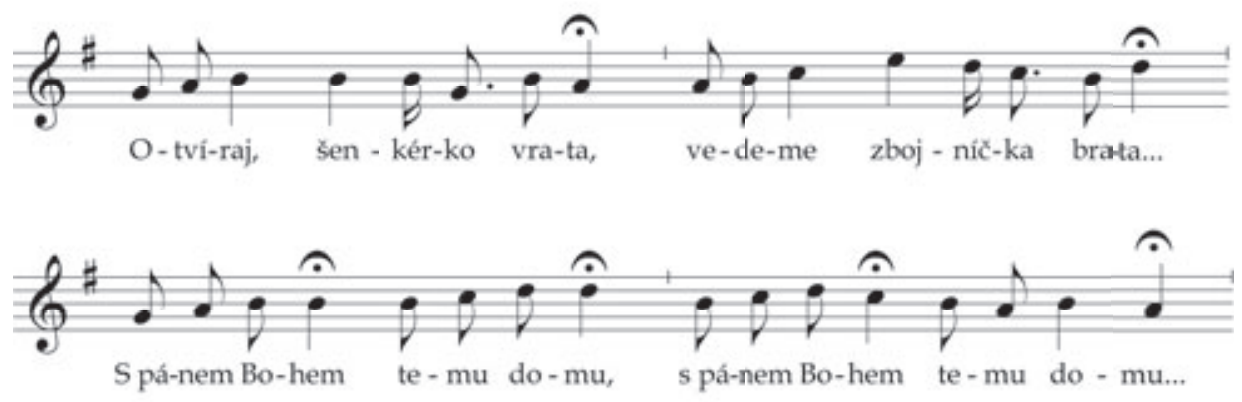

Dříve opatřoval hudební doprovod dudák (gajdoš), v průběhu 20. století postupně nahrazovaný hudci. Vystoupení podšablářů se dnes převážně uskutečňuje v interiérech a v průjezdech domů, kde smyčcové nástroje - stejně jako jejich ladění - nepřízní počasí tolik netrpí. Princip antistruktury (Turner 2004; Chlup 2005) a světa naruby zpravidla umožňoval opouštět konvenci a jindy panující vnitřní cenzuru (Bachtin 2007: 98, 99) na úkor různých excesů, včetně hudebních. Avšak větší míra konzervativnosti prostředí ve Strání umožnila vstoupit do tradičního nástrojového obsazení pouze akordeonu či několika akordeonům, většinou však v dětském podání. Maškarády oproti Borskému Mikuláši a Dobrkovské Lhotce v obchůzkové pasáži rituálu přítomny nejsou. Těm je vyhrazena až liminální situace večerní taneční zábavy.

Z hlediska využití hudby, zpěvu a tance se jeví fašank ve Strání jako rozmanitý, současně však vázaný pevnou vnitřní strukturou, ustáleným sledem písní, charakteristickým tanečním krokem a uskupením tanečníků. Zřejmě i proto 
tanec pod šable dlouhodobě vyvolával a stále vyvolává vlnu zájmu folkloristů a kulturologů, kteří se jej snaží zařadit do širšího historického a kulturního kontextu evropského i mimoevropského (cechovní tance, vojenské tance, kurucké, maurské, turecké vlivy). ${ }^{15}$ Při výzkumu roku 2016 jedna ze skupin podšablářů uplatnila následující sled písní, respektive jejich strof:

\section{Při vstupu do domu}

1. Otvíraj, šenkérko, vrata

2. Dva koně v maštali stojá

Hudba, zpěv a tanec začínají pozvolnou, ale razantní chůzí s údery šavlí o zem, tempo se postupně zrychluje a začínají se střídat figury mečového tance (respektuje se původní interpunkce)

Horenka hora, zelená hora

Volá mřa volá, frajárka moja

Ej, horenka horuje, ej, děvenka banuje

Ej, nebanuj, nebanuj, ej, nemáš co banovat Pod šable, pod šable, aj pod obušky

Tute nám nedali, tute nám dajů

Ej, Javorinka šedá, ej, kdo pod tebú sedá

Ej, jak ho zabijali, ej, tak mu povídali

Ej, prečo tá, Židáčku, ej, prečo táa zabili

Dzinky, dziny od dzedziny

Gajdoš, gajdoš, dobrý gajdoš

Ej, na strañanskej věži, ej, dva kosárky visá

Ej, kebych já byu věděl, ej, že ňa budú věšat

Ej, šibeničky dvoje, ej, kerá bude moje

Ej, dívča nemoje, prehodím tá pres oje

Hop, dívča mariáš, z turkyniska boty máš

Vytínání. Po úvodním pochodu vybraný tanečník - odvedený voják v předklonu přes židli dostává od svých druhů údery tak, že úder dopadá na šavle ostatních tanečníků.

Na tú svatú Katerinskú nedělu

Počkejte vy, radní páni, za chvílu

Ked' ty budeš poskakovat za milů

Ked'sa budi̊ nohavičky prášiti

\section{Vběhne do kola děvče, odvedence vyplatí}

Společný tanec. Následuje po vytínání spolu s pohoštěním. 
Na novej hore, na novej hore

Ženy přistoupí k chlapcům a tančí společně straňanskou.

Při pohoštění nechybí slivovice, koblihy, koláčky, uzené, slanina, popřípadě se gazdovi na kopí zavěsí další klobáska, lahev pálenky, uzené.

\section{Odchod z domu}

\section{S pánem Bohem temu domu}

Hudební styl písní a doprovodné hudby je ovládán prvky novouherské hudební kultury. Výhradně se uplatňuje dvoudobý takt, zcela převažují rytmické figury s lombardskými a tečkovanými rytmy a duvajový doprovod.
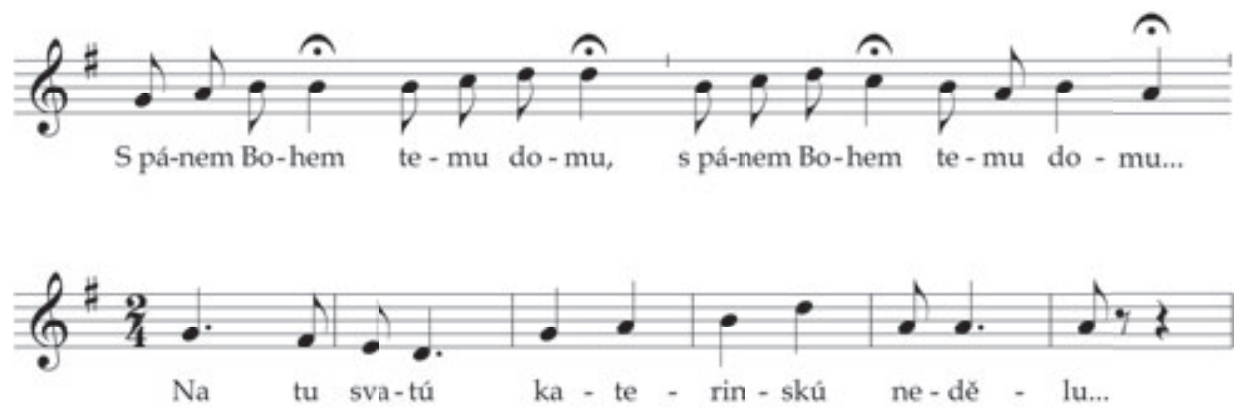

S dudami zřejmě již na přelomu 19. a 20. století odešel autochtonní hudební styl a píseň Gajdoš gajdoš, dobrý gajdoš, uplatněná v hudební součásti rituální sekvence, je reminiscencí nejen dříve oblíbeného nástroje ale i stylu s dudami spojeného. Durový tónorod a dnešní tónina in $\mathrm{D}$, ve které probíhá hlavní část hudby $\mathrm{k}$ tanci podšablářů, vyhovuje právě hudcům. Pouze sestava s dominujícím akordeonem si vynutila hráčsky jednodušší tóninu in F. - Rytmický stereotyp oživují na východní Moravě a také zde ve Strání časté velké trioly a razantní charakter hudby zdůrazňuje řinčivý zvuk kovových kroužků upevněných na nýtech dřevěných šavlí. Tanečníci jsou současně zpěváky, zpívají zpravidla jednohlasně, vždy a všude s plným nasazením. Z publika se někdy přidává druhý hlas.

Taneční prostředky nejsou nepodobné těm v Borském Mikuláši. Pohyb základního kola se uskutečňuje proti směru hodinových ručiček. Gazda naopak (v Dobrkovské Lhotce Matka masopust) obchází kolo v protisměru. Základem je poskočný, podtrhávaný krok, pohybové varianty počínají pokládáním šavlí na rameno předchozího tanečníka, následuje přetáčení, překračování, podlézání šavlí, respektive brána, překřížení šavlí do tvaru růžice s efektními poklepy šavlí a jejich kování.

Muzikou večerní taneční zábavy je dechovka, tvořená žesti a bicími. Klarinety přítomny nejsou, přiznávku obstarává výrazný bubínek. Pod zpívanou melodií se uplatňuje tenor s barytonem, v mezihrách se blýsknou 
křídlovky. Kvalita hudebníků, dechařů, je pozoruhodná, jejich produkce probíhá vestoje. Na dva dvoudobé takty polky se tančí jeden třídobý valčíkový krok, do tance se zapojují páry různých generací a v páru tančí mladí se starými, děvčata s děvčaty. Hrají se a tančí bezvýhradně polky a valčíky ve velmi rychlých tempech. Pouze při expozé jednotlivých skupin koledníků podšablářů se dechovka odmlčí a tančí se i straňanská, která „ty odjinud“ rychle odhalí. Taneční krok jim činí nepřehlédnutelné potíže.

Zlom přichází o půlnoci. Zatroubí ponocný a do zcela zaplněného a zhasnutého sálu vstupuje smrt s kosou. Za ní průvod s basou a její naříkající pozůstalí. Prahová, liminální situace je téměř totožná s tou v Borském Mikuláši. Kněz v ornátu s biretem a štolou čte levity svým farníkům. Maskami pohřebního průvodu jsou jen muži a muži převlečení za ženy. Je to chvíle, na kterou se všichni celý rok těší, a náramně se baví. Poté průvod odejde, basa je pochována. Nastává postliminální fáze, popeleční stř̌eda a s ní velikonoční půst předzvěst velikonočních rituálů.

Masopustní koleda v Dobrkovské Lhotkce ${ }^{16}$ je z vnějšího pohledu ze tří porovnávaných rituálů nejpestřejší, nejbarevnější. Barevnost je korunována vysokými klobouky, svátečními obleky a šerpami skupiny koledníků. Za barevností je však skrytá nepoměrně hlubší symbolika ukřižování Ježíše Krista: podle dlouhodobě tradovaného podání halapartna hejtmana s nabodnutým masem znamená kopí, kterým byl Kristus probodnut na kř́iži. Šerpa koledníků (hantuch) je roucho, které zahalovalo Kristovo tělo. Pět červených karafiátů a jalovec na kloboucích symbolizují pět ran Krista Pána a trnovou korunu. Lopatkami rybníkářů má být vykopán Kristův hrob, sekerou, kterou nosí s sebou, jíž byl přibit Kristus na kříž. Dva rybníkáři jsou lotři, se kterými byl Kristus ukřižován. Maškary putující s koledou jsou Židé, kteří křižové cestě přihlíželi. Čepice nebo přilby s kohoutími péry jsou symbolem zapření Krista. Na taškách maškar (cígrech) jsou symboly neposkvrněného početí Panny Marie (někdy již parodované a inovované), vysoké klobouky jsou ozdobeny růžičkami, kterých je 365, jako dnů v roce.

Rituál masopustního úterý začíná ráno strojením masek, obšíváním koledníků do šerp a oslovením starosty s prosbou o povolení koledy. K hlavním postavám rituálu patří Masopust nebo také Matka-masopust. Přes rameno nese cep, jeho úder označí místo, kde se koleda zastaví a uskuteční hlavní rituální prvek kolo. První kolo se koná v hospodě, odkud vychází skupina koledníků a dalších masek na nejdelší část koledy, obchůzku po obci. V podvečer, oproti masopustním rituálům na Slovensku a na Moravě, je obchůzka zakončena unikátním střetem s druhou skupinou koledníků, slaměnou koledou složenou ze starších, všedně oděných mužů. Jde o dialogové divadlo končící slovním

16 Výzkumy uskutečněné v letech 2001, 2002 a 2005 byly ukončeny publikací a zvukovým CD (Kratochvíl - Tyllner 2007). Současně probíhal výzkum Daniely Stavělové završený dvojjazyčnou publikací a multimediálním CD (2008). 
i fyzickým soubojem a usmířením obou koledních skupin. Ani zde nechybí kněz, ministranti, odsouzení Masopusta a nakonec jeho zastřelení. Večer následuje „věneček“, společenská zábava, na kterou byli pozváni všichni obyvatelé domů, kde se koleda uskutečnila. Zábava má přesný pořádek zajištěný především tancmástry, kteří vybírají ženy k tanci (nejdříve zasnoubená děvčata, potom všechny svobodné ženy místní, dále svobodné přespolní atd.). Koledníci a maškary i večer během věnečku zůstávají ve svém obřadním oděvu.

Kolo tančí šest až devět koledníků a každý z tanečníků má přesně stanovenou funkci, která se vyznačuje různými atributy a předměty. Za hejtmanem vyzbrojeným halapartnou s nabodnutým uzeným masem následuje rychtár̆, který má feruli (rychtářské právo), konšel s žezlem, dva tancmajstři s věnečkem a myrtou, myslivec s dřevěnou flintou, popřípadě žitný (nosíval žito), ovesný (nosíval oves) a koledník. Kolo je předváděné opakovaně u každého domu s oslovením jednotlivých členů domácnosti a jejich pozváním do věnečku, večerní taneční zábavy. Potom následuje tanec s obyvateli domu v polkovém nebo valčíkovém taktu a koledníci jsou zpravidla pohoštěni slivovicí, koblihami nebo uzeným masem. Je reálným předpokladem, že tanečníci byli původně rovněž vyzbrojeni šavlemi (minimálně to dokazují ikonografické dokumenty pořízené u německého etnika ještě v období mezi světovými válkami).

Nejen meče, ale také obvyklé nástroje jihočeské lidové hudby (dudy, housle, klarinet dř́ve i cimbál) se již z koledy vytratily a hudební doprovod dnes tvoří malá dechová hudba s akordeonem (trubka, klarinet, tenor, baryton, tuba, bicí, akordeon, jindy trubka, saxofon, velký buben, bubínek, akordeon). Ke kolu tančenému vždy před každým domem je hrána jedna ze tří protokolárních písní:
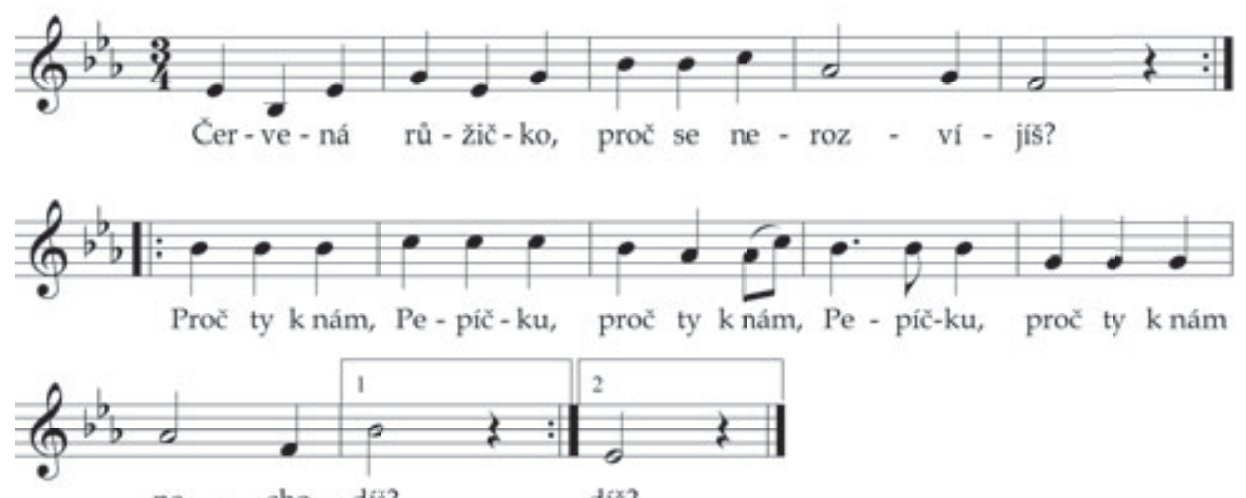

ne - cho - dis? dis?

Z nich pouze píseň Červená růžičko, proč se nerozvíjiš svým textem naznačuje souvislost s vlastní koledou. Z hlediska funkčnosti zbývající dvě písně (Kůn̆ vraný, sedlaný, Mám já obrázek, mám) mohou být nahrazeny kteroukoli jinou 
valčíkovou písní. Jejich poměrně nevýrazný rytmický tep způsobuje, že otočky zavíjení kola tanečníci provádějí bez přísné vazby na rytmus písně.

Pochodové písně místních muzikantů zaznívají při přechodu od domu $\mathrm{k}$ domu. $\mathrm{O}$ velmi hlučné zvukové pozadí se starají maškary, které doprovázejí koledníky. Využívají zejména píštalky, myslivecké vábničky, celá obchůzka je provázena salvami z primitivních děl. Jedna z hlavních masek, Matkamasopust, má přišit ke kalhotám mezi nohama kravský zvonec, klonbu, která bývala běžná na pastvách u krav a která vydává charakteristický všudypřítomný zvuk provázející celý rituál od počátku do konce. Zvláštní úlohu má kapela při střetu obou koled, kdy fyzický a slovní souboj je doprovázen tomu přizpůsobenou hudbou.

Protože hudba v průběhu celodenní obchůzky hraje především tři písně, které provázejí koledníky při obřadním kole, hudebníci nutnou monotónnost narušují množstvím na místě improvizovaných variací. Do nich se vyhráváním rytmu melodií zapojuje i buben. Při ranní př́ípravě na koledu a při večerním věnečku však kapela již využívá svůj obvyklý repertoár, v němž dominují dnes nejen na jihočeském venkově převažující polky a valčíky. Věneček trvá od pozdního odpoledne do ranních hodin, čímž je úloha hudby v rámci rituálu ukončena. Výkon hudebníků je náročný hlavně na fyzickou výdrž a na schopnost střídmé konzumace alkoholu, nebot u každého domu jsou zvláště štědře pohoštěni nejen koledníci, ale i hudebníci, kteří je provázejí. Tanec, zejména polka, v jejímž provedení jsou dva dvoučtvrtové takty vyplněné jedním valčíkovým tanečním krokem, ${ }^{17}$ je v této podobě oblíbený nejen ve Strání, ale rovněž zde na Doudlebsku.

Spektrum zvukové palety, jakousi akustickou clonu, dotvářejí i další zvuky rituálu. Jejich povaha a intenzita se mění podle podmínek a charakteru prostředí a podle míry prožitku účastníků. Můžeme mluvit o akusticky nevýrazném, jakési napětí vyjadřujícím obřadním šumu, stejně jako o zvukově vydatném souhrnu všech vydávaných zvuků, provázejících jednotlivé fáze koledy. Z tohoto zvukového pozadí vystupují nejen všudypřítomné zvuky zmíněných píštal, děl, klaksonů, pyrotechniky, muziky, ale také proslovy hlavních aktérů koledy, zejména hejtmana, který při obchůzce oslovuje všechny obyvatele, jimž je kolo věnováno. Stejně modulovanou obřadní řečí hovoří oba hejtmani slovního souboje sváteční a slaměné koledy či farář provádějící zpověd' Masopusta. Rozloučení s Masopustem, jeho pochování doprovází smuteční pochod, ${ }^{18}$ uzavírající hudebně-žánrové spektrum základní části masopustní koledy. Následující zábava, věneček, končí absolutní únavou všech pozdě k ránu.

17 Etnochoreologie pro takovou podobu tance používá pojem „valčopolka“ Př́činou krokové redukce je s největší pravděpodobností pohodlnost, resp. menší fyzické zatížení tanečníků. Jde o variantu revoluční písně Pryč s tyrany a zrádci všemi. 
Basilejská Fasnacht je kontrastujícím příkladem rituálu velkého západoevropského města oproti agrárně-patriarchálnímu prostředí středoevropského venkova. Její datum konání nekoreluje s masopustem naším. ${ }^{19}$ Datum určují protestanté odlišně důsledkem nezapočítávání nedělí do počtu předvelikonočních dnů. Proto se basilejská Fasnacht uskutečňuje o týden dříve než katolický konec masopustu. Nápadných rozdílů je však ve srovnání se švýcarským městem více. Fasnacht začíná v pondělí v 04.00 hodin ráno údery věžních hodin (Morgenstreich) a končí ve čtvrtek ráno ve stejnou hodinu (Endstreich). Ačkoli trvá tři dny, fenomén Fasnacht ovládá Basilej celý rok. Exploze kreativity si vynucuje důkladnou, dlouhodobou přípravu.

Fasnacht má rysy karnevalu ve smyslu rušení nerovnosti uvnitř společenství a nese charakter „světa naruby“ ve kterém je dán průchod obvyklému napětí kumulovanému intenzivním tepem života průmyslového, stejně jako kongresového či univerzitního města. Obyvatelé města však Fasnacht neztotožňují s karnevalem, volným, téměř nekontrolovatelným a spontánním rejem masek. Při Fasnacht dominuje světská politická a lokální satira, nadsázka, literární, výtvarná a zejména hudební tvořivost.

Fasnacht je skoro rodinným svátkem, který si Basilejci dělají pro sebe. Diváci jsou pouze trpěni. Lidé se baví sami mezi sebou a nechtějí se nechat vyrušovat. Proto se jistá intolerance projevuje vůči těm, kteří přicházejí zvenku a ruší. Navíc se zde mluví dialektem, ostatně Švýcarsko je zemí dialektů. Rovněž multikulturalita (až $40 \%$ jiných národností) je ve městě nepřehlédnutelná.

Kreativita je programově tematicky vyhraněná a formuje se v prostředí klik, jakýchsi cechů či sdružení, která mají své ideově závažné nebo naopak humorné syžety. Kliky mívají až 400 členů a rovněž se soustředují na vytváření rozměrných svítících posterů - lateren, které vyjadřují zpravidla sociální nebo politicky úderný program, kritiku nebo satiru. Podobně se formují i skupiny školáků připravující si své masky, larvy, a svítící lucerny nesené na hlavách při raním zahájení a ukončení masopustního rituálu.

Všechny aktivity, at již výtvarné, literární či orální nakonec předčí nepřehlédnutelná a nepřeslechnutelná hudba. Celé kilometry průvodu Morgenstreichu, který začíná na hlavním náměstí před radnicí, jsou tvořeny nejen maskami s lucernami a laternami, ale jejich nositelé téměř bez výjimky hrají na krátké flétny - pikoly doprovázené skupinami bubnů. Jejich hra začne v jeden okamžik o čtvrté hodině ranní poté, co jsou zhasnuta veškerá městská světla a z reproduktorů se ozve povel: Morgenstraich - vorwärts marsch!

Basilejská Fasnacht má svou protokolární, dlouhodobě tradovanou a jen pozvolna modernizovanou hudbu. Nabízí ale také celou řadu hudebních projevů volných, doprovodných, uplatňovaných především mimo úvodní a konečný 
rituál. Zahajovací pochody znají všechny hudební skupiny dětí i dospělých zpaměti, hrány jsou jednohlasně, v některých, spíše výjimečných případech i vícehlasně. Pochod Morgenstraichu je významným akustickým symbolem masopustního třídení a společný nácvik a hra pochodů i během roku představuje významnou volnočasovou aktivitu mladých školáků stejně jako dospělých členů klik. Hudba masopustu tak v důsledcích vytváří podmínky pro společenské styky, sociální vazby a pro integraci pestrého etnického složení města.

Svou strukturu má pořadí hudebníků v průvodu: přední pozice je určena kapelníkovi, za ním kráčí pištci a nakonec bubeníci. $\mathrm{V}$ téměř nekonečných zástupech se hra stovek skupin prolíná, což vytváří charakteristický tónový chaos. Trajektorie průvodu je vymezena historickým centrem (tzv. velkou Basilejí) a soupeřící novou částí za Rýnem ( tzv. malou Basilejí). Některé kliky jsou čistě hudební a jejich členové se na novou Fasnacht připravují brzy po skončení té předcházející. Basilej má dokonce hudební školy, připravující žáky pouze pro tyto tři dny v roce a stejně tak účelově profilované výtvarné ateliéry.

Mimo protokolární část hudebního repertoáru v provedení hráčů na pikoly a bubny se hojně uplatňují dechové hudby, jejichž prestiž v Evropě vůbec je nevídaná, oproti téměř opovržení, se kterým se setkávají u nás, ačkoli právě úroveň našich dechovek je stále mimořádná. Basilejský kocept masopustu nakonec necílí na estetickou kvalitu. Vyžaduje hlučnost, nápadnost, spektakulárnost. Masky, zejména jejich hlavy svou nadměrností a nepoměrem k tělu navíc vyžadují atypické držení a způsobují nesnadný vstup nátrubku nebo ústic pikol do úst hudebníků. Šanci dostávají i malé, o to však hojnější a rafinovanější skupiny hudebníků, kráčející v roztodivných kostýmech především o volnějším masopustním úterý kř́ižem krážem městem. Nepovinná seskupení nástrojů s pestrým, často i swingovým repertoárem se uplatňují při Cortege, průvodech kapel a alegorických vozů. Rozdávány jsou při nich bonbóny, zelenina, exotické ovoce a přihlížející jsou zasypáváni papírovými Räppli. Při Cortege se prosazují zejména velké nástrojové bandy s bateriemi suzafonů vypouštějících ze svých korpusů doslova dělové salvy.

V dojmu z basilejské Fasnacht nakonec nedominuje pouze nevázanost a bujarost. Př́ítomno je i téma smrti a mnohé masky evokují spíše expresionisticky vyjádřenou úzkost než radost. Některé kliky po ukončení rituálu pouštějí po Rýnu malé rakve, symbol konce zimy, ale i stále přítomné smrti (Cieslarová 2013: 123).

V Basileji o Fasnacht jsou více než kde jinde prostřednictvím anonymních masek popřeny hierarchie a společenské rozdíly. Deformované, neproporční tváře larev nutně vedou ke konfrontaci mezi sebou samým (nositelem masky, a tím i nositelem změněné identity ) a okolním reálným světem vytvářejícím stav blízký turnerovskému pojmu communitas. Podobně se v Basileji lidská individualita ztrácí za hudebními nástroji, které působí jako masky tentokrát však v rovině zvukové (Lévi-Strauss 2006: 42). 
Jedním z projevů basilejské masopustní antistruktury je i protiklad hudby ostrých diskantových pikol, bubnů a nejrůznějších hudebních uskupení, stojících tváří v tvář k tradičně vysoce kultivované hudební kultuře města, které ukázalo vlídnou tvář i českému hudebnímu skladateli Bohuslavu Martinů v nejdramatičtějších okamžicích jeho života. ${ }^{20}$

\section{Závěrem}

Do prostoru článku nebylo cílem vtěsnat veškeré detaily a nuance průběhu rituálů konce masopustu a počátku velikonočního půstu. Cílem bylo podchycení alespoň některých univerzálií a naopak jedinečností spojených s hudbou, pravidelnou součástí těchto rituálů. Hudba se v nich uplatňuje především v rámci obchůzky a jen latentně deklarovaných přání utilitárního charakteru. Kolední rituály, obchůzky stavení, dvorců se u starých Slovanů uskutečňovaly především v prostředí zemědělského venkova (městský kolednický rituál měl odlišnou strukturu i konečný cíl) s výrazně patriarchálními rysy, kdy aktéry obchůzky jsou muži. Hudba v takových rituálech uplatněná se postupně stala jedním z kódů přispívajících $\mathrm{k}$ jejich porozumění stejně jako dlouhodobému tradování ve stabilně, petrifikované podobě. Není vnějším pomíjivým koloritem nebo excesem, ale v důsledcích napomáhá k integraci a prosperitě společenství v širokém časovém oblouku života generací. Hudba v rituálu usnadňuje komunikaci mezi těmi, kdo rituál uskutečňují a prožívají a těmi, kteří jsou jeho svědky, publikem. Ukázalo se, že hudba ve zkoumaných příkladech včetně basilejské Fasnacht je k rituálu ve dvojím vztahu: přímo závislém, kdy se stává jeho znakem (hudební projevy protokolární), nebo nezávislém, volném (arbitrálním). U fašanku ve Strání se uplatňuje celý soubor protokolárních melodií. S hudbou uplatněnou v rituálu, v našem případě zejména na moravsko-slovenském pomezí a na Doudlebsku, úzce souvisí tanec, který často formuje metrorytmickou strukturu hudby. Také on plní stejnou protokolární funkci jako hudba, která je jeho součástí. ${ }^{21} \mathrm{~V}$ basilejské Fasnacht však tanec ve spojení s hudbou zcela absentuje. Př́́kladů, kdy rituál je přímo sdílen hudbou (hudba jako otisk rituálu) jak bylo ukázáno na počátku textu, je minimálně. ${ }^{22}$ Hudba je ve většině př́ípadů, řečeno s nadsázkou, zbavena zobrazovacích pout.

Děje blíže charakterizovaných čtyř masopustních rituálů lze interpretovat v duchu van Gennepovy klasifikace přechodových rituálů s klíčovým rysem

Dirigent Basilejského komorního orchestru Paul Sacher (1906-1999) poskytl pohostinství hudebnímu skladateli Bohuslavu Martinů (1890-1959) v době Mnichova a na počátku jeho emigrace z republiky, do které se již nevrátil. A Basilej se mu stala místem boje o život, který se ani přes mimořádnou péči basilejských lékařů a přátel Bohuslava Martinů nepodařilo zachránit. Kupř. v Bulharsku na svátek sv. Jiří jsou hudba (zpěv) a tanec k sobě navzájem v podobně úzkém vztahu. Ten zde dospěl do podoby tzv. asynchronního chora.

22 Vedle Stravinského Svěcení jara představuje v české hudební literatuře podobný případ kantáta Otvírání studánek (1955) Bohuslava Martinů na text Miloslava Bureše. 
liminální (prahové) fáze a stejně tak je možné aplikovat pojmy communitas a antistruktura Gennepova pokračovatele Victora Turnera.

Oproti představám zastánců „,autentického“ folkloru nachází v rituálech českého, moravského a slovenského prostředí uplatnění akordeon. Je nástrojem univerzálním, mobilním, hlasitým a schopným obstarat nejen melodii a rytmus, ale také harmonii, což u nás ani na Slovensku takto spolehlivě nedokáže jiný folklorní hudební nástroj. Estetická funkce hudby v rituálu není prvořadá, na kráse hudby nezáleží. Kvalita interpretace často odpovídá podmínkám, za kterých se koná. V Borském Mikuláši zastihla koledníky značná sněhová nadílka a mráz, basilejskou Fasnacht zase vytrvalý déšt. Nástrojové obsazení, oproti obvyklým sestavám lidové hudby, není normováno a pokud ano, pak se řídí odlišnými pravidly (Basilej). Výraz hudby má často extatickou podobu, ve Strání zpěv někdy přechází až do výkřikủ. Archaické, i když řídké modální prvky mohou ukazovat na hloubku hudební tradice především na Slovensku a na Moravě, nikoli však na území Čech.

Hudba je v podmiňující interakci k rituálu a je jeho stimulem. Děj rituálu koreluje s hudbou, která určuje rytmus jeho změn. Hudebník v rituálu je individuum vyjadřující se hudebním nástrojem. „Hudba je nonverbální způsob komunikace“ (Nettl 1983: 24), a ten je v rituálu uplatněn vrchovatě.

Zář́r 2016

\section{Literatura}

Bachtin, Michail Michajlovič. 2007. François Rabelais a lidová kultura středověku a renesance. Praha Argo.

Barthelmes, Barbara - De la Motte-Haber, Helga (eds.). 1999. Musik und Ritual. Fünf Kongressbeiträge, zwei freie Beiträge und ein Seminarbericht. Mainz: Schottt.

Cieslarová, Olga V. 2013. Fasnacht v Basileji karneval? Praha: Brkola.

Eriksen, Thomas Hylland. 2008. Sociální a kulturní antropologie. Příbuzenství, národnostní příslušnost, rituál. Praha: Portál.

Frolec, Václav. 1982. Lidová obyčejová tradice a obřadní kultura. Terminologické otázky. Národopisné aktuality 19: 252-271.

van Gennep, Arnold. 1909. Les rites de pasage. Étude systématique des rites. Paris: É. Nourry.

van Gennep, Arnold. 1997. Přechodové rituály. Systematické studium rituálů. Praha: Lidové noviny.
Gluckman, Max. 1962. Essays on the ritual and social relations. Manchester: Manchester University Press.

Goldschmidt, Anne. 1989. Handbuch des deutschen Volkstanzes. Wilhelmshaven: Florian Noetzel Verlag.

Chlup, Radek. 2005. Struktura a antistruktura - Pojetí rituálu Victora Turnera. Religio 13: 3-28; 179-197.

Janáček, Leoš. 1955. Pod šable. Tanec mečový na naší domácí půdě. In: Leoš Janáček o lidové písni a lidové hudbě. Ed. Jiří Vysloužil, Praha: Státní nakladatelství hudby a umění: 235-236.

Kratochvíl, Matěj - Tyllner, Lubomír. 2007. Masopustní koleda na Doudlebsku. Praha: Etnologický ústav AV ČR, v. v. i.

Kresánek, Jozef. 1951. Slovenská ludová pieseň so stanoviska hudobného.

Bratislava: Slovenská akadémia vied. Lévi-Strauss, Claude. 2006. Mythologica. Syrové a vařené. Praha: Argo. 
Nejkova, Ruža - Fol, Valerija. 2000. Огън и музика. София: Академично издателство „Проф. Марин Дринов“.

Nettl, Bruno. 1983. The Study of Ethnomusicology. Twenty-nine Issues and Concepts. Urbana: The University of Illinois Press.

Nodl, Martin - Šmahel, František (eds.). 2014. Slavnosti, ceremonie a rituály pozdního středověku. Praha: Argo.

Pospíšil, František. 1911. Mečový (zbrojný) tanec na slovanské půdě. Národopisný věstník českoslovanský 6: 25-55.

Rappaport, Roy A. 2002. Ritual and Religion the Making of Humanity. Cambridge: Cambridge University Press.

Stavělová, Daniela. 2008. Červená růžičko, proč se nerozvíjišs. Doudlebská masopustní koleda: tanec, identita, status a integrace. Praha: Etnologický ústav AV ČR, v. v. i.
Tyllner, Lubomír. 2010. Tradiční hudba. Hledání kořenů. Praha: Etnologický ústav AV ČR, v. v. i.

Turner, Victor. 1969. The Ritual Process: Structure and Anti-Structure. Chicago: Aldine Publishing.

Turner, Victor. 1982. From Ritual to Theatre: The Human Seriousness of Play. New York: PAJ Publications.

Turner, Victor. 2004. Průběh rituálu. Brno: Computer Press.

Vavák, František Jan. 1802. Smlouvy, aneb chvalitebné řeči svatební. Kutná Hora.

Zíbrt, Čeněk. 1895. Jak se kdy v Čechách tancovalo. Praha: František Šimáček. 